\title{
Dynamic political contexts and power asymmetries: the cases of the Blue Nile and the Yarmouk Rivers
}

\author{
Hussam Hussein ${ }^{1}$ Mattia Grandi ${ }^{2}$
}

Accepted: 15 March 2017/Published online: 21 March 2017

(C) The Author(s) 2017. This article is an open access publication

\begin{abstract}
This paper explores the evolving patterns of hydropolitical relations in the dynamic contexts of Yarmouk and Blue Nile Rivers in comparison. The analysis aims at shedding light over the complex implications that recent political and social changes have aroused for the water disputes between Jordan and Syria on the one hand, and Ethiopia and Egypt on the other. In both basins, cooperative efforts toward the integrated management of transboundary waters have been only partially effective and largely undermined by the perpetuation of unilateral actions by riparian states. In the case studies, the lack of a basinwide vision over the control and use of shared waters has resulted in disputes among the basin states and ultimately in an unsustainable, unfair, and unwise utilization of the resources. This paper argues that a substantive and effective integration of national water policies is unlikely to occur, unless power asymmetries are properly addressed in order to overcome the likelihood of hegemonic regimes.
\end{abstract}

Keywords Hydropolitics · Transboundary water interactions · Nile River Basin · Yarmouk River · Power asymmetries · Hydrohegemony

\section{Introduction}

The Arab region has most of its surface water originating outside of its countries, and transboundary waters (TBW) represent over two-thirds of its overall water resources (UNESCWA 2013). In this region, the mainstream approach to water resources management has been mostly subjugated to engineering, which is finding solutions through technical

Hussam Hussein

h.hussein@uea.ac.uk

1 Water Security Research Centre and Tyndall Centre for Climate Change Research, School of International Development, University of East Anglia, Norwich, UK

2 Sant' Anna School of Advanced Studies, Pisa, Italy 
and politically "neutral" perspectives. The dominant paradigm of the hydraulic mission has strongly guided and supported this principle. The hydraulic mission is a key concept in the study of hydropolitics and refers to the mission of the state in solving the issue of water scarcity through large projects and hydraulic infrastructural development. In so doing, it also aims at increasing its socioeconomic and political stability (Allan 2001). This paper argues that a broader assessment over the specific context in which water disputes occur could shed light upon subtle and hidden dynamics that affect TWM, through the identification of issue linkages and wider interstate relationships. This could ultimately lead to a substantive shift from a watershed-oriented perspective to a multilevel "problemshed" focus (Allan 2001), in order to overcome the limitations of looking at the water sector in isolation.

The two case studies that are the focus of this article are the Egyptian-Ethiopian relations over the Nile River and the Syrian-Jordanian relations over the Yarmouk River. Both cases lack a basin-wide shared vision on the use and allocation of the basin water resources, thus resulting in unilateral actions and bilateral agreements rather than integrated action plans agreed upon by all the basins' states. In addition, political and social changes that have recently taken place in the Middle East and North Africa have impacted the hydropolitical dynamics in the cases considered. This article addresses the causes of shifting power relations in the Yarmouk and Nile basins: The two case studies, although presenting many differences (including hydrogeological features, hydropolitical history, and nature of decision-making processes), show a relative erosion of the hydrohegemonic basin states, Egypt and Syria, and witness the, partially successful, strategies of counterhydrohegemonic resistance developed by the less powerful riparian states.

This work first discusses different theoretical stances in the hydropolitical literature on the securitization of water issues. Second, it examines the relevance for this study of the framework of hydrohegemony $(\mathrm{FHH})$, the role of power asymmetries, and the concept of power. Third, it applies the theories presented to the two empirical cases of this work: the Nile and the Yarmouk basins. Finally, it discusses the findings and contributions that emerge in the analysis. In doing so, this paper aims at contributing to the critical hydropolitical literature emphasizing the role of the broader context in the analysis of power dynamics in transboundary contexts.

\section{Transboundary water management (TWM) reconsidered}

This section discusses the tension between the progressive depoliticization of water governance in the political agenda and the narrowing of solutions for water-related challenges to the watershed level of analysis in the literature on TWM (Allan 2003; Wester et al. 2003). These approaches are largely adopted in the MENA region, and this section aims at showing the limitations that these perspectives present, suggesting a new way to overcome these pitfalls.

Water resource management (WRM) is inherently a complex political process, which reflects and in turn determines "the balance between environmental, economic, and social values of water" (Butterworth et al. 2010: 74). This happens through the determination of water allocation, uses, related norms, and ultimately water rights. Thus, natural resource management and politics are strictly interconnected.

Politics is to be understood as a process rather than an arena, and the conceptual definition of the term clearly states that "at its broadest, politics concerns the production, 
distribution, and use of resources in the course of social existence" (Heywood 2002: 10). Yet, the mainstream literature tends to emphasize a de-politicized understanding of the challenges that water management is facing in the twenty-first century (Castro 2007). This happens despite the fact that in recent years not only a heterogeneous body of academics (for instance Allan 2003; Wester et al. 2003), but also international organizations such as the World Bank have recognized the political nature of WRM. ${ }^{1}$

Since the early 1990s, issues related to the management of natural resources have gained popularity in the political agenda (Buzan et al. 1998), whereas they were previously considered as "low politics" matters, as if they were not vital for ensuring the security of the polity (Jackson and Sørensen 2016). Nevertheless, this trend of inclusion of environmental issues into the political arena has increasingly shown a tendency to securitize them (Buzan et al. 1998). According to the Copenhagen School, securitization is a "discursive construction of particular issues as security threats" (McDonald 2008: 1) that demands for extraordinary measures in order to deal with that specific challenges. A successful securitizing move represents "a failure to deal with issues of normal politics" and therefore leads to the "depoliticization" of the issue addressed (Buzan et al. 1998: 29) by excluding it from the arena of political debate. One interpretation of the concept of securitization/ depoliticization recalls that " $[\mathrm{u}]$ pon acceptance by the audience, the issue is said to have moved out of the sphere of normal politics and into the realm of emergency politics, where it can be dealt with swiftly and without the normal rules and regulations of policy-making" (Floyd 2010: 1).

This process of securitization not only has hindered the political debate over policy alternatives, but has also contributed to relegate resource-related issues to the realm of allegedly neutral and merely technical problem-solving approaches. This issue of securitization of water resources in transboundary basins has been recently studied in the case of Cyprus by Zikos, Sorman, and Lau (Zikos et al. 2015). Nachmani also addressed issues of geopolitics in water scarce countries in the Middle East, fusing on Cyprus and calling for further research at a regional basis (Nachmani 2000), while the recent literature is developing and focusing for instance on Israel and Palestine (Messerschmid 2012; Mason 2013; Zeitoun et al. 2013).

As emerges in the book "Social Water Studies in the Arab Region," the main debate over TWM in the MENA region is dominated by technical approaches, which assumes that managerial perspectives should consider water issues as "objective and neutral," thus overlooking the specificity of political aspects, games, contexts, and relationships, at domestic as well as at international level (Fayyad 2015).

It results that on the one hand, environmental issues became an integral part of the political agenda. On the other hand, instead of being fully recognized in the "realm of the possible" and subjected to open and public debates toward the formulation of appropriate policies, they ultimately resulted deprived of their inherent political nature. This happened through processes of depoliticization, silencing alternative voices and visions, and prioritizing the "neutrality" of technical and managerial "objective" strategies.

The acknowledgment of the political features inherent in water-related issues could be addressed considering the broader political context, which for Turton (Turton 2005: 1) "brings together the physical attributes" with the challenges of (water) development. This

\footnotetext{
1 See World Bank (2003: 3): "The main management challenge is not a vision of integrated water resources management but a "pragmatic but principled" approach that respects principles of efficiency, equity, and sustainability while recognizing that water resources management is intensely political and that reform requires the articulation of prioritized, sequenced, practical, and patient interventions."
} 
is where processes of norms diffusion take place and power plays influence the outcome of complex water interactions. Heywood (2002) highlights in his analysis how politics has to be understood in terms of power and distribution of resources (Heywood 2002). For Heywood "politics is therefore a struggle over scarce resources, and power is the means through which this struggle is conducted" (ibid.: 10). Power results to be a central concept to unpack the broader political context. The dimensions of power and the dynamics of political relationships beyond the mere water sector are thus to be explored to address the complexity of water-related issues. The urgency of broadening the focus of analysis beyond the managerial aspects of technical solutions for water policies leads to the identification of heterogeneous variables. Those variables are of social, economic, political, economic, and environmental character, and they account for the very nature of the specific topic to be addressed in the analysis. In a nutshell, we need to look at the broader context to understand and solve water challenges.

To address the broader and complex interactions that forge water-related issues, the development of an approach encompassing such a variety of observations external to the water sector is required. Some analysts suggest a shift in focus for targeting "problemsheds" rather than "watersheds," incorporating in this way multiple variables external to the water sector (among others Allan 2001; Earle 2003). As per Cohen and Davidson (2011: 4), watersheds "rarely encompass all of the physical, social, or economic factors impacting upon the area within its borders." Instead, a problemshed-focused approach could enable a better understanding of often hidden dynamics that play a core role in shaping water policies and hydropolitical relationships among different actors (Cohen and Davidson 2011). The role of the agent in water politics has thus to be contextualized within a relational web of multiple dimensions. Ultimately, this lies outside the water sector: "We ought to contextualize social and political action within the structural context in which it takes place" (Jägerskog 2003: 88 on Hay's (1995) concept of contextualization of agency). ${ }^{2}$ This study builds on Lowi's (1995) work, which underlines the necessity of considering - in certain cases - the sociopolitical contexts to analyze TWM (Lowi 1995). Transboundary water challenges are an excellent case for accounting these topics and provide a fertile ground for the development of multidimensional analyses of international water disputes.

In this section, we have briefly sketched two critical tendencies underlying the development of the water politics literature in the last few decades: the trend of depoliticization of the water governance conceptualization in the political agenda and the narrowing of solutions for water-related challenges to the watersheds unit of analysis. These factors combined could reasonably result in a partial and biased understanding of the complexity around water disputes and water policy measures. One possible way to solve this analytical limitation is therefore to expand the focus of research beyond the mere water sector toward a more comprehensive problemshed-approach. This would encompass the political dimensions and the complex interactions for a critical geopolitics of water that could overcome the pitfalls of the mainstream water literature.

\footnotetext{
2 According to Jägerskog (2003: 88), “As Hay (1995) points out, agents/actors are never to be analyzed apart from their context. He calls this the contextualization of agency." See also Zikos et al. (2015) on the interaction between biophysical and social sub-systems.
} 


\section{Multidimensional power and the framework of hydrohegemony}

This section, after briefly discussing the development of the literature on critical hydropolitics, presents Lukes' conceptualization of power and discusses the relevance of the FHH for this work.

The issue of conflicts over water resources in transboundary river basins has recently become a focal point for political studies. Several authors focused on the potential for future "water wars" as a consequence of increasing demands for water (Homer-Dixon 1994: 5-6). However, the scholarship has refuted these claims (Allan 2001; Wolf et al. 2003). Other scholars showed that water scarcity could be a reason for dialogue, regional cooperation, and peace (ibid.). For instance, according to Allan (2001), political economy policies and the import of virtual water, which is the amount of water needed to produce goods and services, are one of the reasons for which countries are not going to wage war over water. The literature is developing around the different intensities of conflict and cooperation regarding international waters, and the key role of power relations in the hydropolitical transboundary relations (Zeitoun and Warner 2006; Cascão 2008, 2009; Zeitoun and Mirumachi 2008). Water, as also seen in the previous section, is recognized as a political issue.

In this work, we emphasize the necessity to look for gray areas rather than black and white. This means that cooperation and conflicts in TWM can coexist rather than being seen as a dichotomy. ${ }^{3}$ Zeitoun and Mirumachi (2008), as well as Cascão (2008), dismiss the "either/or" approach that sees conflict and cooperation as two opposite of a continuum, as different and hermetic steps of negotiation processes. On the contrary, their analyses stem from the assumption that conflict and cooperation coexist, and that "not all cooperation is pretty." In this way, the focus is on the interdependency of both and on the complex and wider interactions that water issues embed for the actors involved.

Central to this analysis is the concept of power and the power asymmetries to understand how and why hegemonic control is gained and maintained. This is important for this work because in a problemshed approach, power is determinant in explaining shifting TBW relations. Zeitoun and Warner's (2006) FHH is useful for our analysis as it incorporates the concept of power in explaining how and why hegemonic control over TBW is gained and maintained (Zeitoun and Warner 2006: 435). The FHH suggests considering power asymmetries besides the riparian position (downstream or upstream along the river) and the exploitation potential. For the purposes of the present work, the analysis on the case studies will mainly focus on the pillar of power and on the different dimensions of power. Cascão (2009) argues that non-hegemonic countries can challenge the hegemonic configuration by using (mainly) soft power, known in the FHH as bargaining and ideational power, in order to shift dominant ideas. Issues linkages to gain more bargaining power or the "boomerang strategy," based on connections with international actors in order to put pressure on riparian states, are some counter-hegemonic tactics that aims at challenging the status quo (Fischer 1981; Keck and Sikkink 2002; Daoudy 2009).

The concept of power used in the FHH is taken from Lukes' conceptualization of the three dimensions of power. The first dimension of power considers "overt power," known as "material power" in the FHH. This "hard power" is a clearly visible power, such as military and economic power resources. The second dimension of power is "covert

\footnotetext{
${ }^{3}$ Cascão (2012): "the future of cooperation in the Nile Basin is not 'black or white': The choice is not between full cooperation on the one hand and noncooperation on the other. On the contrary, there exists a large gray area, and the different emerging scenarios involve their owncomplexities."
} 
power," the ability to have control over the political agenda and to decide what to discuss and what is left off the agenda. This dimension of power, known in the FHH as "bargaining power" includes skills, strategies, and tactics adopted by the different actors to exert more power over negotiations and influence the political agendas. Lukes' third dimension of power is structural-known as "ideational" power in the FHH. It is the power of shaping perceptions, preferences, and choices, making people accept the status quo as natural, influencing actors' understanding of the possibilities of change (Lukes 1974; Scott 2008). It can be exercised to shape, influence, or determine the very wants of "B" (the subordinate, the ruled over; adapted from Dahl, R. in Zeitoun and Warner 2006: 442). In this way, a mainstream discourse can for instance influence people's perception over water resources.

As seen in the FHH, understanding the role of power is fundamental in order to analyze how the water resources in a basin are allocated among the different actors. It is necessary to take into consideration power asymmetries in order to understand and explain the distribution of the transboundary water (TBW) resources, as showed for instance by Zeitoun (2008) in the case of the Lower Jordan River. In that case, Israel is the hydrohegemonic actor, controlling the vast majority of the aquifers and of the Lower Jordan River shared among Israelis, Jordanians, and Palestinians (Zeitoun 2008: 45-49).

A growing number of scholars have recently contributed to the framework in order to strengthen and improve it in many different ways. While according to Selby (2007) the FHH focuses only on the international sphere, ignoring the national and transnational contexts, Warner and Zawahri (2012) contributed to fill this shortcoming by calling for the FHH to consider multiple levels. At the same time, Lopes explored the role of the European Union in the Iberian case, showing the relevance of considering non-state actors to explain TBW distribution (Selby 2007; Lopes 2012; Warner and Zawahri 2012; Zawahri and Hensengerth 2012). Nevertheless, in the case studies selected bilateral relations are still the main determinants in shaping and deciding allocation and uses of the water resources of the two basins, whereas non-state actors struggle for proper recognition of their role in the hydropolitical dynamics considered. Existing and previous water agreements along the two river basins are of bilateral nature, the main contentious on the management and allocation of shared waters are between two of the riparian states in both basins, and crucial intra-basin policies are directly negotiated by high-level politicians rather than by technical interstate groups. For these reasons, the focus of this article is over water-related bilateral relations between Egypt and Ethiopia and between Syria and Jordan, in the Nile and Yarmouk Rivers, respectively. The FHH has strongly improved as several scholars have successfully used it in different basins in the past years. However, the FHH risks overlooking the context, ideologies, history, and cultures supporting hegemonic architectures, given its focus on outcomes (water allocation) rather than processes (Conker 2014). The framework is being further developed and improved by scholars in the field (among others, Mirumachi 2015; Menga 2016a, b; Menga and Mirumachi 2016; Zeitoun et al. 2016a, b). Mirumachi (2015) consolidates and further elaborates on the role of exploitation capacity and potential of riparian states and on the material element of hydrohegemony. Finally, Menga (2016b) recently discusses the overall fluid nature of hydrohegemony and counter-hegemony, for which a consolidated status quo might be challenged to the point that hegemonic and non-hegemonic roles could swap. Therefore, we would like to contribute to the FHH debate through emphasizing the role of the political context when analyzing TWM, which is the central focus of this paper. In this way, it will be possible to understand the processes of consolidation of hydrohegemony and water allocation and understand how and why changes occur. 


\section{Asymmetric power balance and the threat of "water wars" over the Nile}

A growing number of media's sensationalist headings over the Nile waters' disputes have proliferated in recent years, such as "Egypt and Ethiopia spar over the Nile," 4 "Egypt rules out war with Ethiopia," "Egypt and thirsty neighbors are at odds over Nile." 6 The media headlines contributed to securitize the Nile waters management and the hydropolitical relations between Egypt and Ethiopia. The following analysis is intended to shed some light upon the complex interactions that arise from the broader political dynamics in what narrowly is believed by media (not by academics) to be the incumbent "Egypt's water war."7

Considered the longest river of the world, the Nile flows across eleven countries and is the major water source for irrigation or hydropower production in most of its riparian states (Fig. 1). In particular, due to its hydrologic and climatic features, Egyptians' dependency upon the discharge of the Nile waters is crucial for the very survival of its economy: The Nile waters account for 94\% of Egyptian total water resources, and 97\% of Egyptians are dependent on its water (Cascão 2009; NBI 2012). Since Egypt is the far downstream country of the basin, its reliance on the Nile flows has historically characterized the fragile balance of the hydrologic equilibrium in the whole region. In addition, the physical attributes of the river draw a particular conformation of the water flows, due to the fact that two main tributaries account for the overall discharge of the Nile waters: the Blue Nile, which arises in Ethiopia and constitutes the $86 \%$ of the overall Nile volume (Swain 2011), and the White Nile, which proceeds from the Lake Victoria and merges with the Blue Nile north of Khartoum. Nowadays, population growth and cyclic droughts, poverty and food insecurity, pollution and environmental degradation, migration and water scarcity, overgrazing and desertification, climate change and hydraulic exploitation represent serious challenges to the effective management of Nile flows. These challenges, combined with historical grievances related to intra-regional politics, exert a renovated pressure over the resources of the basin, threatening the stability of the whole area (Ibrahim 2010).

\subsection{Historical grievances over the use of the Nile waters}

The hydrologic conformation denotes a peculiar geopolitics of water in the basin, given the fact that historical confrontations on the allocation and use of the Nile waters have historically seen Egypt and Ethiopia as main contendents (Tvedt 2009). The former has been exerting a (quasi) hegemonic influence over the riparian states of the whole basin and strenuously defended its acquired rights over the Nile waters, ${ }^{8}$ while the latter has been fighting for the recognition to an increased share of the flows supplied by a river that has never been exploited by the Ethiopians at its full potential. Despite there have not been

\footnotetext{
4 Al Jazeera America, February 6, 2014, available online at http://america.aljazeera.com/opinions/2014/2/ egypt-disputes-ethiopiarenaissancedam.html;.

5 Bloomberg, June 26, 2013, available online at http://www.bloomberg.com/news/2013-07-26/egypt-rulesout-war-with-ethiopia-over-nile-river-hydropower-dam.html.

6 The New York Times, September 25, 2010, available at http://www.nytimes.com/2010/09/26/world/ middleeast/26nile.html?pagewanted=all\&_r=0.

7 The Times of Israel, May 30, 2013, available online at http://www.timesofisrael.com/egypts-water-war/.

8 In particular, Egypt relies upon the water agreements of 1929 between Britain and Egypt, and the 1959 treaty between Egypt and Sudan: Both deny allocation of Nile waters' quotas for the upstream countries.
} 


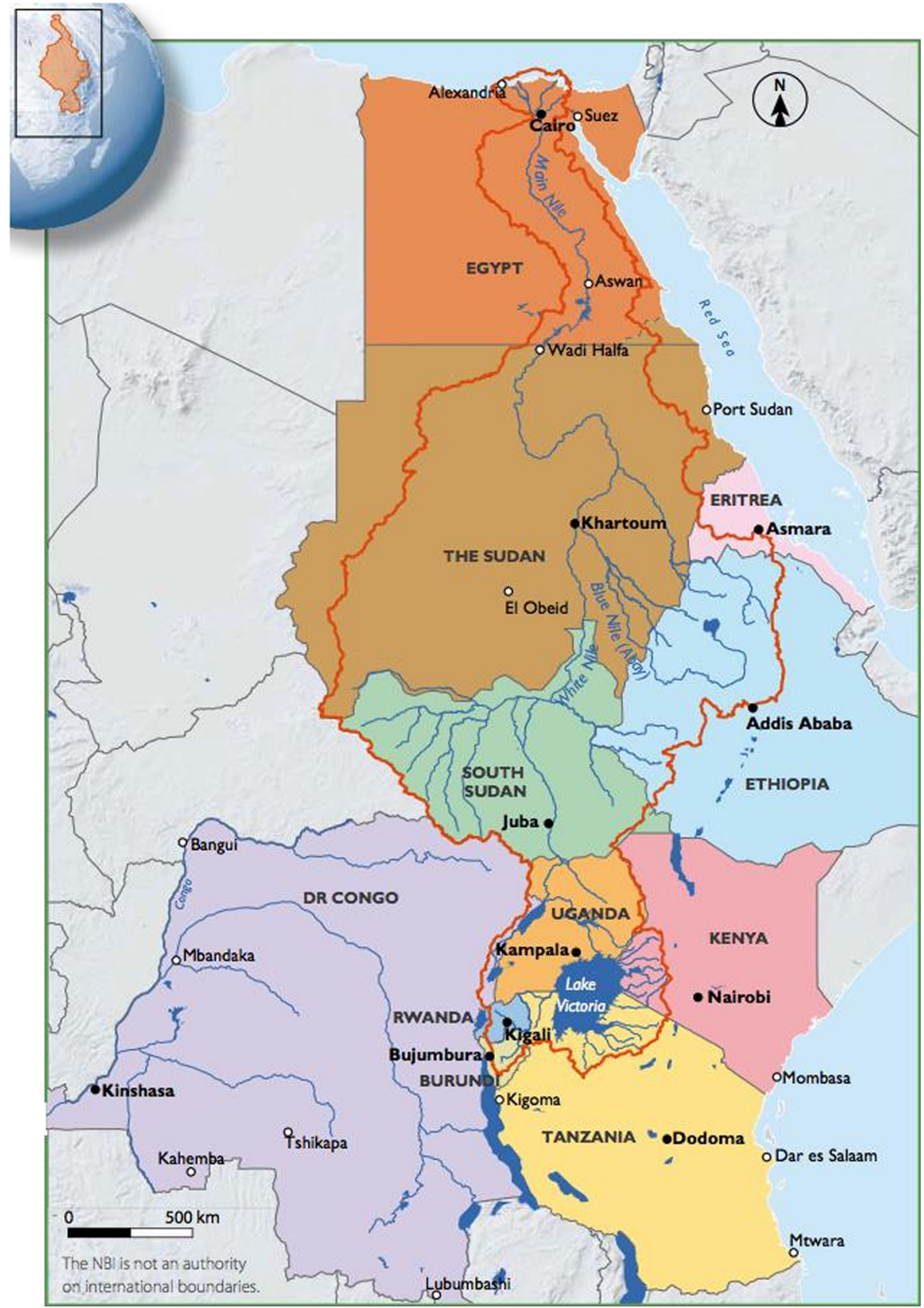

Fig. 1 The Nile River Basin. (source: NBI 2012)

military confrontations between the two countries since the Egyptian invasion of present Eritrea in 1876 (Yohannes 1999), the disputes between Ethiopia and Egypt over the allocation and use of the Nile waters have not only historically affected their relationships 
in creating an environment of reciprocal mistrust throughout the twentieth century, but they are also likely to induce a state of uncertainty for most of the twenty-first century.

The reasons of current tensions on the Nile are not to be searched in elusive changes suddenly occurred in recent years, such as the building of the Great Ethiopian Renaissance Dam (GERD), but rather they have to be considered as outcomes of historical processes that have shaped the broader political context in the Nile in the past centuries. According to Lautze and Giordano (2005), the very cause of present stiff confrontation between upstream and downstream states lies in the agreements signed in colonial era, which since then have contributed to influence successive negotiations over the control of the Nile flows. The authors suggest that the most important colonial Nile agreements were bilateral and not basin-wide, bounded to Britain' interests, and concluded largely on power inequalities which have favored the flourishing of Egyptian economy at the cost of Ethiopia's and other downstream states' interests (Waterbury 1979; Lautze and Giordano 2005). According to this interpretation, the exclusion of Ethiopia from the pivotal water agreement of 1929 between Britain and Egypt, and from the 1959 treaty between Egypt and newly independent Sudan (in addition to the failed 1902 Anglo-Ethiopia agreement), has provoked the emergence of the Ethiopian resentment toward the Egyptians and decisively contributed to the creation of an hostile environment for successive negotiations between the two countries (Rahman 2011). Moreover, Rahman (2011) states that the Ethiopian development in terms of economic growth, political stability, and military power after the fall of Menghistu's regime in 1991 and the 1998-2000 conflict with Eritrea has turned Ethiopia into a powerful and influential nation capable of opposing the Egyptian hegemony in the region.

\subsection{Evolving power relationships in the Blue Nile basin}

Zeitoun and Warner's FHH constitutes a useful tool for the analysis of current hydropolitics in the Eastern Nile River Basin. The assumption that in contemporary TWM power presents different faces beyond the mere military and economic features contributes to reveal the complexity of water-related issues in intricate political contexts, and provides the theoretical tool for the identification of the "pillars" of hydrohegemony. A revised version of the pillars appears in Cascão and Zeitoun (2010), ${ }^{9}$ where the authors analytically emphasize the role of Lukes' second and third faces of power in shaping the hydropolitical patterns among transboundary rivers riparian states: Beside geographic features, the pillars thus include material, bargaining, and ideational power, as illustrated in the previous section. The main assumption of these prominent authors is that Ethiopia has led the "upstream block" in a diplomatic challenge against downstream hydrohegemony, succeeding in eroding Egypt's bargaining power through an increasing ability of voicing the interests of upstream countries (Cascão and Zeitoun 2010). Their determination to be fully recognized as legitimate actors for fair agreements over the allocation, use, and management of the Nile waters has been made explicit during the long-lasting negotiation process that set up institutions such as Hydromet, Undungu, the Tecco Nile, the Nile Basin Initiative (NBI), and the projected Nile Basin Commission (NBC).

Cascão and Zeitoun (2010) assume that a consistent increase in the bargaining strength of Ethiopian-led upstream block corresponds to a relative erosion of Egyptian bargaining power, which counterbalances the non-hegemons' weaknesses in other power dimensions.

9 Cascão (2008) already conceived this configuration of hydrohegemony, adapted from Zeitoun and Warner (2006). 
The negotiation process aimed at the creation of the NBI at the beginning of the 1990s has seen progressive Ethiopian attempts to influence the rules of the game (Arsano and Tamrat 2005) and to set control over its agenda. As a result, all the riparian states were included into the negotiations, ${ }^{10}$ and, even more importantly, the legal determinants for a new inclusive agreement that could supplant the previous 1929 and 1959 treaties on the allocation of the Nile waters have been raised at the core of the NBI agenda. However, the resistance by downstream hydrohegemon Egypt and its political ally Sudan to upstream riparian states' challenge to the consolidated status quo has been explicit throughout all the decade-long negotiation processes within the NBI framework. The participation of these two countries to the negotiating table is likely to have occurred with the final goal of keeping Egyptian traditional influence and compliance-producing mechanisms ${ }^{11}$ over the other states involved, in order to procrastinate the adoption of a comprehensive agreement where the reallocation of Nile quotas could erode the "acquired rights" of the downstream countries. As argued by Daoudy (2008), this strategy of "active stalling" is a conventional tool commonly used by hydrohegemons in order to oppose possible challenges to the status quo (Daoudy 2008, 2009).

\subsection{Strategies of counter-hegemony: the water-energy nexus in the Nile basin}

The relative erosion of Egypt's bargaining power vis à vis Ethiopia's gains in the same power dimension could also be explained by the analysis of the modifications in the structure of incentives exploited by the hydrohegemon in order to deploy consent-producing strategies. Egypt has traditionally represented the largest economy in the region, which has maintained a formidable military sector strictly interconnected with political authorities. Moreover, its strategic alliances with global powers such as both the US and the USSR, and more recently the European Union, have not only contributed to increase its economic performances, but especially have coroneted Egypt as the legitimate hegemon in a regional framework of political instability, economic insecurity, and low development (Cascão 2008). Indeed, with the purpose to pursue its national interests, Egypt has been successful in consolidating its role as regional hegemon, either co-opting or silencing the alternatives advanced by the other Nile riparian states. The deployment of consent-inducing strategies has allowed Egypt to benefit from compliance-producing mechanisms, which have contributed to undermine the claims of upstream states and to strengthen the Egyptian supremacy over the regional agenda. The trade-off between the potential benefits of bandwagoning (or leastwise not competing with their healthier neighbor) and the risks associated with open challenges to the Egyptian power has notably contributed to the preservation of Egypt's leadership, which in turn has been functional for the preservation of its hydrohegemonic power over the basin.

Current tensions over the Nile also arose from this changing pattern in the ability to provide benefits to neighboring countries: While Egypt's influence in the region has sharply decreased due to NBI negotiation processes with downstream Nile riparian states, ${ }^{12}$ political turmoil and economic crises, shifting international alliances and gradual access to international markets for downstream countries, Ethiopia is recently replacing its historical

\footnotetext{
10 This outcome is not only due to Ethiopia's commitment to the negotiation process, but also to the international efforts that have supported the establishment of the NBI, most notably the World Bank.

11 The concept is adopted from Lustick (2002) in Zeitoun and Warner (2006).

12 An alternative view sees the NBI as a strategic tool controlled by Egypt in order to expand its ideational power over the downstream countries.
} 
enemy as "benefit provider" in the region. Commercial exchanges with the Nile states (both in terms of goods and services) have historically conveyed Egypt's political leadership (through bilateral as well as multilateral arrangements) and the expansion of its economic capacity (in term of investments, financing of developmental projects and aid channeling). The same strategy has been recently put in place by Ethiopia, as a countermove to Egyptian hegemony at regional level, with the aim of providing the other riparian states with major benefits from the Ethiopian exploitation of the Nile waters, especially in the energy sector. Between 2011 and 2013, Ethiopia signed energy deals with Djibouti, Kenya, and Sudan for the sale of 1,500 MW and the construction of interstate transmission lines, and more of such agreements are planned for the period 2016-2020 (UNECA 2014). The energy development plan of the Ethiopian government foresees a sharp increase in both the national power generating capacity, from $4180 \mathrm{MW}$ in 2015 to $2017,208 \mathrm{MW}$ by 2020 , and the energy production capacity, from 9515 GWH in 2015 to 2063,207 GWH by 2020 (GoE 2016). According to governmental estimates, $80 \%$ of national energy capacity (nearly 14,000 MW) will be generated from hydropower by 2020: If successful, the Ethiopian strategy of exploitation of the Nile hydroelectric potential for exporting energy could lead to a possible win-win opportunity for both the generating country and neighboring states in look for cheaper energy. Actually, recent development of hydroelectric power infrastructures over the Nile tributaries in the Ethiopian territory could be interpreted not only as a measure to exploit the hydrogeological potential of the Nile waters for economic revenues (or a threat to Egypt's share of the Nile flows, as per the Egyptian perspective), but also, and maybe more substantially, as a deliberate strategy to raise consensus among the riparian states by providing cheap energy in exchange of political alignment: The rationale for this assumption is indeed that Ethiopia is not only using water for energy development, nor exclusively trading electricity for gaining economic surpluses, but rather it is deploying a compliance-producing strategy in order to achieve predominance in the dimension of bargaining power. Recent statements by Sudanese President alBashir reasonably represent the main evidence of the changing pattern of alliances in the region, where the role of Sudan is crucial in determining the future outcomes of Nile hydropolitics: While historically aligned with the Egyptian hydrohegemon in terms of political outlook over the management of the river waters, Sudan has been gradually shifting its perspective in favor of Ethiopia's claims, also because of the opportunity of concluding favorable energy deals. ${ }^{13}$ This move could represent a relevant change in the political context of the Nile basin and contribute to erode the acquired status of regional hegemon for Egypt, while at the same time it favors relative gains in bargaining power for Ethiopia (and the upstream block that supports it), which is now more comfortable in setting not only the NBI agenda, ${ }^{14}$ but also bilateral negotiations with each of the Nile riparian states.

\subsection{Fluid hydropolitics: overthrowing the hegemon in the Nile basin?}

This section showed how the power balance on TBW between Ethiopia and Egypt has subtly shifted and how that has opened up new points of dispute. Whether these recent

\footnotetext{
13 See al-Bashir's interviews to newspaper reporters from Sudan Tribune (http://www.sudantribune.com/ spip.php?article50831), Ahram online (http://english.ahram.org.eg/NewsContent/1/64/88412/Egypt/ Politics-/Sudans-Bashir-ignored-impact-of-Ethiopias-dam-on-E.aspx) and Le Monde Diplomatique (http:// mondediplo.com/blogs/egypt-s-diplomatic-card-game-on-the-blue-nile).

14 See Cascão and Zeitoun (2010) for an insightful analysis over the shifting bargaining power asymmetries.
} 
changes will drive the negotiation process toward either more cooperative and inclusive arrangements among the basin states or to a situation of coexistence of bilateral agreements with unilateral infrastructure developments, or finally to the rise of Ethiopia as new hydrohegemon in the region, is still uncertain. We claim that the dispute between the confronting states over the Nile waters is unlikely to escalate into an army conflict, since the recent development in the basin's dynamics "demands regional integration" (Verhoeven 2013). At the same time, we also agree with Waterbury's (1997) position when he claims that comprehensive and shared agreements over the optimal use of Nile waters are "utopian" since they "cannot address the unresolved issue of rival demands for the water itself": Thus, intermediate political steps toward less ambitious goals could "avoid destructive unilateralism and shift our gaze from the utopian to the manageable" (Waterbury 1997: 288). A relevant improvement in the relations between Egypt and Ethiopia materialized in March 2015, when a Declaration of Principle over the management of the Nile water was signed in Khartoum by the two states and the Sudanese government, but the concrete outcomes of the agreement are still unpredictable. In the same way, it is uncertain what the role of South Sudan will be in determining intra-basin relationships: Both Egypt and Ethiopia have substantial interests in buying its acquiescence, but the enduring situation of instability in the country blurs any future hypothesis. ${ }^{15}$ The hydropolitical dynamics in the region are rapidly evolving, and "cooperation and unilateralism cannot coexist in the long term" (Cascão 2009: 265): Many alternative scenarios for the future of water management in the Nile River Basin are open, ${ }^{16}$ and the changing power asymmetries in the pillars of the FHH could help explain how a broader analysis beyond the water sector per se provides insightful perspectives on the complex interactions of water-related disputes over the control of the Nile.

\section{Shaping contexts in the Yarmouk basin}

The Yarmouk River is shared among Jordan, Syria, and Israel. The Yarmouk is the most important tributary to the Jordan River, joining the Jordan around 7-9 km south of Lake Tiberias, and is part of the Jordan River Basin. Four tributaries in Syria and one in Jordan are the sources of the Yarmouk River. The Yarmouk flows along the northwest Jordanian border with Syria, between Jordan and the Occupied Golan Heights, and then between Jordan and Israel before bending in the lower part of the Jordan River. Its historic flow is estimated to be 450-500 MCM a year while nowadays its flow is strongly reduced and very variable, going from a maximum of $272 \mathrm{MCM}$ a year in 1963 and a minimum of $35 \mathrm{MCM}$ a year in 2000 (at Adassiya; UN-ESCWA 2013: 187). There is no basin-wide agreement on the water management of the Yarmouk so far, only bilateral agreements between Jordan and Syria (1987) and between Jordan and Israel (1994) (FAO 2009).

This section focuses on the relations between Jordan and Syria on the Yarmouk River. We argue that we need to include political elements into the analysis in order to understand why the 1953 and 1987 bilateral agreements between Jordan and Syria were signed

\footnotetext{
${ }^{15}$ Helmi Shaarawy founder of the Arab and African Research Center argued that "Supporting South Sudan is no longer an option for Cairo. Rather, it is a necessity in light of the impasse and challenges facing Egypt in maintaining its water interests in the Nile and given Ethiopia's audacity to build the Renaissance Dam" (quoted in Aman 2014). At the same time, Ethiopia urges South Sudan to sign the Cooperative Framework Agreement (CFA).

16 See for example the three future scenarios foreseen by Cascão (2009).
} 


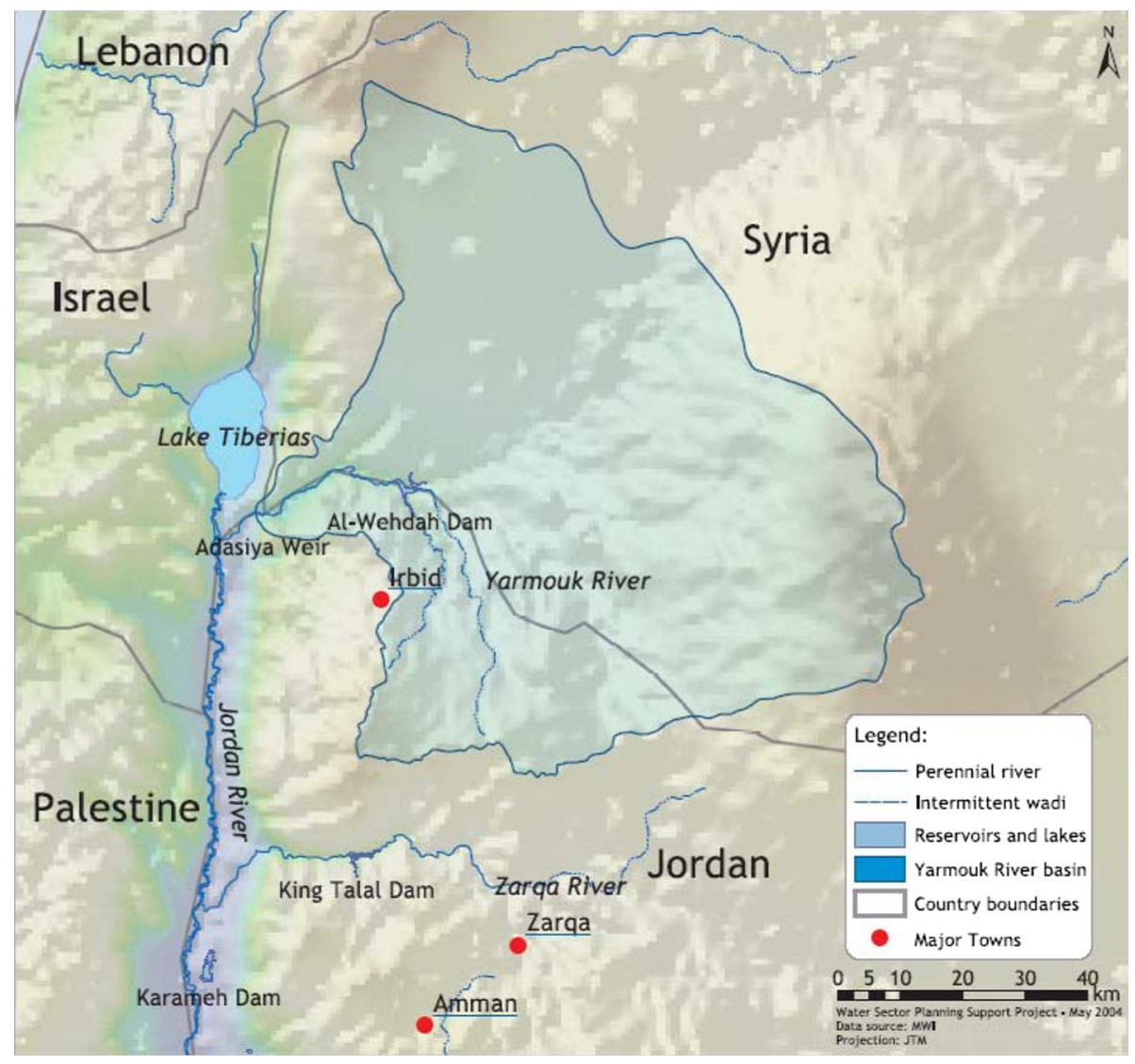

Fig. 2 The Yarmouk River Basin (MWI 2011)

(Fig. 2). Moreover, looking at the quality of these agreements and at the gray areas of cooperation and conflict coexistence, it emerges that in practice the agreements are neither respected nor fully implemented, and therefore, cooperation (the treaties) and conflictive relations (treaties not respected in practice) coexist. Reasons for this can be found expanding the analysis to the broader context, through a problemshed rather than watershed approach, while the mechanisms of water allocation can be explained through the tools provided by the FHH.

As noted by Haddadin (2006, 2012), after 1948, due to the influx of Palestinians to Jordan, the latter had to ensure jobs and food security for the growing population in order to maintain social stability, and water was essential for this (Haddadin 2006, 2012). This socioeconomic context resulted in Jordan commissioning a report, ${ }^{17}$ where Maqarin was identified as a location for storing water from the Yarmouk, instead of Lake Tiberias as suggested by previous plans. Despite being technically feasible, this solution was not adopted: A deep look on the regional dynamics of that time could help explaining the reasons behind the halt of the project. The following geopolitical and socioeconomic contextual aspects backed the plan. First, the USA initially supported the plan in order to

17 Known as the Bunger's report (Haddadin 2006). 
maintain stability in Jordan, backing plans for economic growth and security, opposing in this way a potential communist infiltration in the country. Second, the United Nations Relief and Works Agency for Palestine Refugees in the Near East (UNRWA) supported it, as it would have provided employment and food for the Palestinian refugees. However, the plan was contrary to the interests of Israel, which would have preferred the storage to be in Lake Tiberias, and which had competing plans for the development of the basin. As a result of Israeli complaints, the US economic support was withdrawn and the dam was not constructed (Haddadin 2006). Therefore, in order to understand why change happens or does not happen, we need to consider issues of broader political context, including: the refugees; the need to build and maintain stability in Jordan; the US-Soviet geopolitical context; and the competing plans for the development of the basin. In addition, the FHH helps us in shedding light on why change did not happen: Jordan at that time was not a hydrohegemon country, and therefore, due to power asymmetries, Jordan could not proceed with the project. Actually, Israel was the hydrohegemonic country in the basin, holding relative advantages in the hard, bargaining, and ideational features of power (Zeitoun 2008).

Even if the plan was not developed, the report influenced later projects and treaties for the area. Jordan kept urgently looking for expanding its water supply to secure economic and social development and enhance security in the kingdom. This contributed to reach the first bilateral agreement between Jordan and Syria in 1953, deciding to construct a dam near Maqarin with a capacity of 300 MCM (today's Wahda or Unity dam) and a power generating station at Adasiya for generation of hydropower. The electricity produced at Adasiya was to be allocated on a $75-25 \%$ basis between Syria and Jordan. Jordan agreed to use the overflow of the reservoir and allowed Syria to exploit all water resources upstream of Maqarin (river and its tributaries), with the clause of ensuring enough water to supply the dam (to be constructed). A Joint Water Committee was established to oversee and implement the treaty (Hof 1998; Haddadin 2009; UN-ESCWA 2013). The political context shaped the details of the treaty: For Jordan, water was the priority for maintaining stability, providing food security and employment for its growing population, while for Syria energy was more important than water compared to Jordanians priorities. This treaty resulted in an overall win-win situation: Jordan was to be given more water while Syria was to receive more electricity.

In the early 1950s, the US Ambassador Eric Johnston developed a scheme for the allocation of the Jordan Basin-including the Yarmouk Basin-among the different riparian states. The scheme for the whole Jordan Basin, which only considered agricultural water needs, allocated $616 \mathrm{MCM}$ to Israel, $720 \mathrm{MCM}$ to Jordan (including West Bank), 35 MCM to Lebanon, and 132 MCM to Syria, for a total of 1503 MCM, and identified two storage locations in Lake Tiberias and in Maqarin (Haddadin 2009; UN-ESCWA 2013). It appears that the previous Jordanian report influenced the Johnston Plan identification of two locations, including Maqarin. Concerning the Yarmouk, the plan estimated a flow of $506 \mathrm{MCM}$, and allocated $90 \mathrm{MCM}$ to Syria, $25 \mathrm{MCM}$ to Israel, and the residual (approximately $377 \mathrm{MCM}$ ) to Jordan (including the West Bank), envisioning a 126-m high dam at Maqarin with a capacity of 300 MCM (Hof 1998; Haddadin 2009). The US Ambassador negotiated the Johnston Plan with Israel and the League of Arab States, which, although accepting it on technical bases (as it managed to make Israeli and Jordanian plans for the development of the basin compatible), finally rejected it for political arguments, since it would have resulted in an implicit recognition of Israel. Overall, this scheme is considered to form the basis of successive discussions and negotiations (Hof 1998; Haddadin 2009; UN-ESCWA 2013). 
The case of the Johnston Plan shows that water issues, often discussed on a technical level, are instead deeply political. In fact, in the Johnston Plan case, while a technical agreement over the allocation and uses of the water resources was agreed upon by all riparian states, it was not signed and ratified due to the fact that such technical deal implicitly would have resulted in recognizing Israel, becoming therefore an important political act. At that time, no Arab state had diplomatic relations with or recognized the existence of Israel. Therefore, the political context strongly influences TBW dynamics, as shown in the case of the Johnston Plan. Only a problemshed approach can explain the failure of the plan, as a watershed perspective would not have captured it.

In the 1960s and 1970s, Syria built 26 dams on the tributaries of the Yarmouk without Jordanian approval or consent (Etana Files 2015), it over-exploited groundwater resources recharging the river, and the dam envisioned in the 1953 at Maqarin was not constructed (Haddadin 2009). Looking at the broader context after the 1967 war, when Israel occupied the West Bank, the Jordan Valley on the Jordanian side depopulated from over 60,000 to around 5000 people, villages were destroyed, and farming activities almost completely suspended (Haddadin 2006). As argued by Haddadin, building the dams and not respecting the 1953 agreement were aimed at strongly decreasing the flow of the Yarmouk into Israeli control (Haddadin 2012). However, the relations between Jordan and Syria deteriorated also for regional geopolitical reasons: For instance, Syria supported Iran, while Jordan supported Iraq during the first Gulf War in the 1980s. According to a former Jordanian ambassador, Jordan, overall, could not do much because water "was not on top of the Jordanian priority list, and water was a topic that was given to the engineers. The priorities of our foreign policies toward Syria were: trade, the peace process, and political" (interview 1). ${ }^{18}$ Also for a former Jordanian minister of water and irrigation, it was difficult and almost impossible for Jordan to stop the Syrian violations for several reasons: The political alliances and objectives of the two countries were strongly different, Syria was upstream and Jordan downstream, Jordan had a population of 5 million people while Syria had 25 million people, and the transit trade through Syria for the benefit of Jordan was strategic for the Jordanian government. Jordan had to consider the other sectors and therefore did not and could not do much about the violations of the 1953 agreement (interview 2) ${ }^{19}$ (Hussein 2017). This demonstrates again the necessity of a problemshed rather than a watershed approach to understand why Jordan tolerated the Syrian violations of the 1953 agreement. The FHH provides useful tools to understand the situation between Syria and Jordan: Syria, as emerged from interview 2, is the hydrohegemon country as it has greater hard, bargaining, and ideational power compared to Jordan. Therefore, even if a treaty was in place, Syria was able to decide whether to implement it and respect it or not.

Improved relations between Jordan and Syria between 1985 and 1991, and the new situation on the ground due to previous Syrian violations, brought the two countries to renegotiate a new agreement in 1987. The new agreement outlined: A smaller dam with maximum capacity of $225 \mathrm{MCM}$ and $126 \mathrm{~m}$ high (known as Wahda or Unity Dam) and a reservoir at Maqarin; changed the approach to dispute resolution making it intergovernmental and not subjected to third-parties arbitration (as in 1953), working at Syrian (upstream country and hydrohegemon) advantage; and recognizes Syrian use of the 26 dams on the river and its tributaries and Jordan right to store Yarmouk resources only after the filling of all Syrian dams (Hof 1998; UN-ESCWA 2013). This agreement reflects the evolved balance of power between Syria and Jordan, which means a reinforcement of the

\footnotetext{
18 Interview 1 done in Amman, Jordan, on October 22, 2014, by the primary author of this article.

19 Interview 2 done in Amman, Jordan, on December, 1, 2014, by the primary author of this article.
} 
hydrohegemonic position of Syria. Compared to the 1953 agreement, this new agreement is worst for the Jordanian government as it envisions a dam with a smaller capacity, it recognizes the Syrian dams illegally constructed without Jordanian consent since 1953, and the new approach of dispute resolution works at Syrian advantage.

However, after the 1987 agreement, the relations between Jordan and Syria did not improve on the Yarmouk issue. Syria increased the exploitation of the Yarmouk through building new dams and groundwater drilling, further shrinking the flow of the river (Kubursi 2011). In 2012, Mousa Jamani, Jordanian minister of water and irrigation at that time, stated that "the number of Syrian dams increased from 26 to 48, while around 3500 wells were drilled to pump water from the river basin" without Jordanian consent (Namrouqa 2012).

The Wahda Dam encountered long delays. Bilateral arrangements-and not a third agreement as suggested by Rosenberg (2006) — that took place in early 2000s (2001 for Rosenberg 2003 for Zoubi) reduced the size of the planned dam (Zoubi 2014; Hussein 2017). The Wahda Dam became operational only in 2006 and fully completed in 2009 (UN-ESCWA 2013). Since then, it never reached the full capacity of $110 \mathrm{MCM}$, but its maximum storage was reached in 2009/2010 at 20 MCM (UN-ESCWA 2013) for the years before the Syrian civil war, and since the Syrian civil war started in 2012 the maximum storage of the dam reached $60 \mathrm{MCM} .{ }^{20}$ In addition, the water quality is also deteriorating, with negative peaks in the spring, becoming utilizable only for agricultural purposes (AlTaani 2013). The issue of the decreased flow of the river has been discussed in the Joint Water Committee established with the 1987 agreement and resulted in a joint study on the quality and quantity of the waters in the basin in 2009 (UN-ESCWA 2013). The study aimed at exploring the causes of the decreased level of water and best measures to protect the basin from illegal pumping. In addition, it resulted in the establishment of monitoring stations in the two countries (UN-ESCWA 2013). However, "the solution to Yarmouk Basin water sharing is not technical, it is political," Jamani said (Namrouqa 2012).

Since the outbreak of civil war in Syria in 2011, "the violations over the Yarmouk River and Wihdeh Dam, which currently holds $20 \mathrm{MCM}$ of water, did not increase due to the unstable conditions in Syria, but violations to Jordan's water share remain," Jamani said (ibid.). Recently, an increase in the flow to the Wahda dam was registered. However, it was noted by Jordanian officials that this may be due to a decrease in farming activities in Syria due to the unstable conditions and power cuts, which negatively impacted the pumping stations in the Syrian dams, and not to a Syrian political will to respect the 1987 agreement. Nevertheless, the political instability in Syria is resulting in a shift of the balance of power in favor of Jordan. Jordan has increased its trade relations with other countries, and the importance of Syria for the Jordanian import and export has strongly decreased. This shift in the balance of power, we argue, will also be reflected in the bilateral hydropolitical relations after the Syrian war. Jordanian unilateral actions in the short term and a new agreement in the long term are likely to happen after the end of the Syrian political instability. However, future scenarios depend on the configuration of the future Syrian government and on its take on the regional geopolitical alliances. Nevertheless, in practice this shift of power is currently resulting in an increase in the flow of the Yarmouk reaching Jordan, increasing to $60 \mathrm{MCM}$ since the Syrian civil war started in 2012.

The Jordanian-Syrian relations over the Yarmouk reiterate the necessity to consider TBW relations looking at the quality of agreements and their effective implementation on the ground (Hussein and Grandi 2015). While the presence of a bilateral agreement may

${ }^{20}$ Interview 3 done in Amman, Jordan, on August, 2, 2016, by the primary author of this article. 
look like sign of good cooperation, often agreements are not implemented or are the cause of conflictive relations (Selby 2003; Zeitoun and Mirumachi 2008). In the Yarmouk case, the presence of agreements with Jordan coexisted with the presence of conflictive relations over the allocation of the waters of the Yarmouk. Considering the broader context helped us in understanding why the agreements were reached and also, to some extent, why they were not respected. The FHH helped us to understand why Jordan, which is the nonhydrohegemon country both in relation to Syria during 1953 and 1987, and to Israel during the Johnston Plan, had to change its plans and accept the Syrian violations of the 1953, formalize them in the 1987 agreement, and accept in practice also the continuous violations of the 1987 treaty. In addition, this section showed that by adopting a problemshed approach, it is possible to understand why the flow of the Yarmouk reaching Jordan has increased since 2012 due to the impact of the political instability in Syria. This section also showed the shift in the balance of power between Syria and Jordan and its impact on the allocation of the waters by analyzing the broader political context.

\section{Conclusions}

This paper argues that since the mainstream approach to water resources management has focused on engineering and technical solutions assumed to be politically "neutral," this approach ultimately resulted in depoliticizing water-related issues in policy-making. Given the transboundary nature of most of the water resources in the MENA region, we advocate for the urgency of adopting an interdisciplinary approach in order to account for the complex interactions that water embeds. In particular, we argue that a problemshed approach, rather than a narrow watershed perspective, would allow considerations from the broader context and analyses of power dynamics impacting over the use of shared water resources: TWM is a relative concept determined by social and political process, and denying the role of power relations would hide the causes of change, thus missing the complete picture of water-related dynamics.

The two case studies selected for analysis show significant differences in terms of roles of the actors involved, negotiation processes, hydrogeological characteristics, and broader regional dynamics; nevertheless, this study not only validates some of the hypotheses of the FHH by applying it to different empirical cases, but also theorizes over lessons learned that bring the two cases together. First, both cases show how and why political dynamics (especially power balances) are pivotal in determining policies of TWM. Second, in both basins the regional context influences national water politics and the negotiation processes. Third, in both cases TWM reveals its inherent fluid nature: Rather than being static, hydropolitics show ever-changing patterns of relations (the turmoil in Syria favored relative power gains in Jordan, the unilateral infrastructure developments in Ethiopia impacted over regional relationships), which witness the possibility of challenging the hydrohegemon. Fourth, both cases shed light upon the dimension of bargaining power and the resistance to effective negotiations from the hydrohegemons (Syria agreed to a new agreement with Jordan only after 34 years, and Egypt rejected the Cooperative Framework Agreement as proposed by Ethiopia). Finally, the two cases, although different, help refuting both the "water war" and the "water peace" paradigms, by demonstrating the coexistence of conflict and cooperation in TWM, and the uncertainty of future hypotheses over the evolution of intra-basin dynamics. 
Given the current evolving regional political context, this work only aims to provide analytical insights to be further developed for future empirical researches. Giving a rationale for broadening the perspective in order to look beyond the water sector, this paper represents an attempt to open the box of purely technical water engineering: The interactions observable in the blurred "water governance" concept call for an analytical attitude toward the search for complexities (Zeitoun et al. 2016a, b), and the examples from the case studies illustrated in this work provide the readers with empirical grounds for testing some of the hypotheses advanced in Zeitoun and Warner's FHH.

Open Access This article is distributed under the terms of the Creative Commons Attribution 4.0 International License (http://creativecommons.org/licenses/by/4.0/), which permits unrestricted use, distribution, and reproduction in any medium, provided you give appropriate credit to the original author(s) and the source, provide a link to the Creative Commons license, and indicate if changes were made.

\section{References}

Allan, T. (2001). The Middle East water question: Hydropolitics and the global economy. New York: IB Tauris.

Allan, T. (2003). IWRM/IWRAM: A new sanctioned discourse? SOAS Water Issues Study Group Occasional paper 50. London: School of Oriental and African Studies, University of London.

Al-Taani, A. A. (2013). Seasonal variations in water quality of Al-Wehda Dam north of Jordan and water suitability for irrigation in summer. Arabian Journal of Geosciences, 6(4), 1131-1140.

Aman, A. (2014). Egypt tries to woo South Sudan in Nile water dispute. Al Monitor.

Arsano, Y., \& Tamrat, I. (2005). Ethiopia and the eastern Nile basin. Aquatic Sciences, 67(1), 15-27.

Butterworth, J., et al. (2010). Local approaches to integrated water resources management. Water Alternatives, 3(1), 68 .

Buzan, B., et al. (1998). Security: A new framework for analysis. London: Lynne Rienner Publishers.

Cascão, A. E. (2008). Ethiopia-challenges to Egyptian hegemony in the Nile Basin. Water Policy, 10(S2), $13-28$.

Cascão, A. E. L. F. (2009). Political economy of water resources management and allocation in the Eastern Nile River Basin. London: King's College London, University of London.

Cascão, A. E., \& Zeitoun, M. (2010). Power, hegemony and critical hydropolitics. Transboundary Water Management. Principles and Practice 27-42.

Cascão A. E. (2012). Nile water governance, The Nile River basin: water, agriculture, governance and livelihoods (pp. 229-252). New York: Routledge.

Castro, J. E. (2007). Water governance in the twentieth-first century. Ambiente \& Sociedade, 10(2), 97-118.

Cohen, A., \& Davidson, S. (2011). The watershed approach: Challenges, antecedents, and the transition from technical tool to governance unit. Water Alternatives, 4(1), 1.

Conker, A. (2014). An enhanced notion of power for inter-state and transnational hydropolitics: An analysis of Turkish-Syrian water relations and the Illsu Dam conflict between the opponents and proponents of the Dam. Norwich: University of East Anglia.

Daoudy, M. (2008). Hydro-hegemony and international water law: Laying claims to water rights. Water Policy, 10(S2), 89-102.

Daoudy, M. (2009). Asymmetric power: Negotiating water in the Euphrates and Tigris. International Negotiation, 14(2), 361-391.

Earle, A. (2003). Watersheds and problemsheds: A strategic perspective on the water/food/trade nexus in Southern Africa. Transboundary Rivers, Sovereignty and Development: Hydropolitical Drivers in the Okavango River Basin 229-249.

Etana Files. (2015). The Yarmouk Basin between conflict and development. NGO Etana Files, Report 11.

FAO. (2009). Irrigation in the Middle East region in figures: AQUASTAT Survey-2008. Frenken Karen, Water Reports 24

Fayyad, M., et al. (2015). Social Water Studies in the Arab Region: State of the Art and Perspectives. SLE.

Fischer, R., et al. (1981). Getting to yes. Negotiating Agreement Without Giving in (traduction française, 1982: Comment réussir une négociation) le Seuil (Ed).

Floyd, R. (2010). Security and the environment: Securitisation theory and US environmental security policy. Cambridge: Cambridge University Press. 
GoE. (2016). Growth and Transformation Plan II (GTP II) (2015/16-2019/20). Addis Abeba: National Planning Commission, Ministry of Finance and Economic Development, Government of Ethiopia.

Haddadin, M. J. (2006). Water resources in Jordan: evolving policies for development, the environment, and conflict resolution. Washington DC: Resources for the Future.

Haddadin, M. (2009). Cooperation and lack thereof on management of the Yarmouk River. Water International, 34(4), 420-431.

Haddadin, M. J. (2012). Diplomacy on the Jordan: International conflict and negotiated resolution. Berlin: Springer.

Hay, C. (1995). Structure and agency, Theory and methods in political sciences, 189-206.

Heywood, A. (2002). Politics. Houndsmills. Hampshire: Palgrave MacMillan.

Hof, F. C. (1998). Dividing the Yarmouk's waters: Jordan's treaties with Syria and Israel. Water Policy, 1(1), 81-94.

Homer-Dixon, T. F. (1994). Environmental scarcities and violent conflict: Evidence from cases. International Security, 19(1), 5-40.

Hussein, H. (2016). An analysis of the discourse of water scarcity and hydropolitical dynamics in the case of Jordan. Ph.D. Thesis. University of East Anglia.

Hussein, H., \& Grandi, M. (2015). Contexts matter: A hydropolitical analysis of Blue Nile and Yarmouk River Basins. Social Water Studies in the Arab Region 159.

Ibrahim, A. M. (2010). The Nile Basin cooperative framework agreement: The beginning of the end of Egyptian hydro-political hegemony. Missouri Environmental Law \& Policy Review, 18, 282.

Jackson, R., \& Sørensen, G. (2016). Introduction to international relations: Theories and approaches. Oxford: Oxford University Press.

Jägerskog, A. (2003). Why States Cooperate over Shared Water. The Water Negotiations in the Jordan River Basin.

Keck, M. E., \& Sikkink, K. (2002). Transnational advocacy networks in international and regional politics. International Social Science Journal, 51(159), 89-101.

Kubursi, A., et al. (2011). Water scarcity in Jordan: Economic instruments, issues and options. Economic Research Forum Working Paper Series.

Lautze, J., \& Giordano, M. (2005). Transboundary water law in Africa: Development, nature, and geography. Natural Resources Journal, 45, 1053.

Lopes, P. D. (2012). Governing Iberian Rivers: From bilateral management to common basin governance? International Environmental Agreements: Politics, Law and Economics 1-18.

Lowi, M. R. (1995). Water and power: The politics of a scarce resource in the Jordan River basin. Cambridge: Cambridge University Press.

Lukes, S. (1974). Power: A radical view. London: Macmillan.

Lustick I. S. (2002). Hegemony and the riddle of nationalism: the dialectics of nationalism and religion in the Middle Eas. Logos, 1(3), 18-44.

Mason, M. (2013). Climate change, securitisation and the Israeli-Palestinian conflict. The Geographical Journal.

McDonald, M. (2008). Securitization and the construction of security. European Journal of International Relations, 14(4), 563-587.

Menga, F. (2016a). Domestic and international dimensions of transboundary water politics. Water Alternatives, 9(3), 704-723.

Menga, F. (2016b). Reconceptualizing hegemony: The circle of hydro-hegemony. Water Policy, 18(2), 401-418.

Menga, F. \& Mirumachi, N. (2016b). Fostering Tajik hydraulic development: Examining the role of soft power in the case of the Rogun Dam. Water Alternatives 9(2), 373-388.

Messerschmid, C. (2012). Nothing new in the Middle East-reality and discourses of climate change in the Israeli-Palestinian conflict. Climate Change, Human Security and Violent Conflict 423-459.

Mirumachi, N. (2015). Transboundary water politics in the developing world. Abingdon: Routledge.

MWI. (2011). National water master plan. Amman: Ministry of Water and Irrigation.

Nachmani, A. (2000). Scant resources: The problem of water in Cyprus. Mediterranean Politics, 5(3), 76-94.

Namrouqa, H. (2012). Yarmouk water sharing violations require political solution. The Jordan Times 28 April 2012.

NBI. (2012). The state of the River Nile Basin 2012 (October), Nile Basin Initiative (NBI), Entebbe, October 2012.

Rahman, A. M. (2011). The geopolitics of water in the Nile river basin. Global Research 24.

Rosenberg, D. (2006). The Yarmouk River agreements: Jordan-Syrian transboundary water management, 1953-2004. The Arab World Geographer, 9(1), 23-39. 
Scott, J. C. (2008). Weapons of the weak: Everyday forms of peasant resistance. Yale: Yale University Press.

Selby, J. (2003). Dressing up domination as 'cooperation': The case of Israeli-Palestinian water relations. Review of International Studies, 29(1), 121-138.

Selby, J. (2007). Beyond hydro-hegemony: Gramsci, the national, and the trans-national. In Third international workshop on hydro-hegemony. London School of Economics.

Swain, A. (2011). Challenges for water sharing in the Nile basin: Changing geo-politics and changing climate. Hydrological Sciences Journal, 56(4), 687-702.

Turton, A. R. (2005). Water as a source of Conflict or Cooperation: the Case of South Africa and its transboundary Rivers. CSIR Report 2.

Tvedt, T. (2009). The river nile in the post-colonial age: Conflict and cooperation among the nile Basin countries. London: IB Tauris.

UNECA. (2014). Energy Access and Security in Eastern Africa. Status and Enhancement Pathways. United Nations Economic Commission for Africa.

UN-ESCWA, B. (2013). Inventory of Shared Water Resources in Western asia. Beirut.

Verhoeven, H. (2013). Why a'water war 'over the Nile River won' t happen. Al-Jazeera English. http:// www.aljazeera.com/indepth/opinion/2013/06/2013612105849332912.html.

Warner, J., \& Zawahri, N. (2012). Hegemony and asymmetry: multiple-chessboard games on transboundary rivers. International Environmental Agreements: Politics, Law and Economics 1-15.

Waterbury, J. (1979). Hydropolitics of the Nile Valley, Contemporary issues in the Middle East series. New York: Syracuse University Press.

Waterbury, J. (1997). Between unilateralism and comprehensive accords: Modest steps toward cooperation in international river basins. International Journal of Water Resources Development, 13(3), 279-290.

Wester, P., et al. (2003). Boundaries of consent: Stakeholder representation in river basin management in Mexico and South Africa. World Development, 31(5), 797-812.

Wolf, A. T., et al. (2003). International waters: identifying basins at risk. Water policy, 5(1), 29-60.

World Bank (2003). World Bank water resources sector strategy: strategic directions for World Bank engagement. Washington DC: World Bank.

Yohannes, A. (1999). The Hydropolitics of the Nile. Retrieved from http://www.ethiopians.com/abay/ nilepolitics.html.

Zawahri, N. A., \& Hensengerth, O. (2012). Domestic environmental activists and the governance of the Ganges and Mekong Rivers in India and China. International Environmental Agreements: Politics, Law and Economics 1-30.

Zeitoun, M. (2008). Power and water in the Middle East: The hidden politics of the Palestinian-Israeli water conflict. London: IB Tauris.

Zeitoun, M., \& Mirumachi, N. (2008). Transboundary water interaction I: Reconsidering conflict and cooperation. International Environmental Agreements: Politics, Law and Economics, 8(4), 297-316.

Zeitoun, M., \& Warner, J. (2006). Hydro-hegemony-a framework for analysis of trans-boundary water conflicts. Water policy, 8(5), 435-460.

Zeitoun, M., et al. (2013). The influence of narratives on negotiations and resolution of the upper Jordan river conflict. International Negotiation, 18(2), 293-322.

Zeitoun, M., et al. (2016a). Transboundary water interaction III: Contesting hegemonic arrangements. International Environmental Agreements. doi:10.1007/s10784-016-9325-x. (published online).

Zeitoun, M., et al. (2016b). Reductionist and integrative research approaches to complex water security policy challenges. Global Environmental Change, 39, 143-154.

Zikos, D., et al. (2015). Beyond water security: Asecuritisation and identity in Cyprus. International Environmental Agreements: Politics, Law and Economics, 15(3), 309-326.

Zoubi, M. (2014). Benefit sharing, water and cooperation: The Jordanian case. Turkish Review, 4(3), 276. 